\title{
Transposon vector-mediated stable gene transfer for the accelerated establishment of recombinant mammalian cell pools allowing for high-yield production of biologics
}

\author{
Natalie Tschorn $\cdot$ Karen Berg $•$ Jörn Stitz $\mathbb{D}$
}

Received: 4 November 2019/Accepted: 13 April 2020/Published online: 22 April 2020

(C) The Author(s) 2020

\begin{abstract}
Stable recombinant mammalian cells are of growing importance in pharmaceutical biotechnology production scenarios for biologics such as monoclonal antibodies, growth and blood factors, cytokines and subunit vaccines. However, the establishment of recombinant producer cells using classical stable transfection of plasmid DNA is hampered by low stable gene transfer efficiencies. Consequently, subsequent selection of transgenic cells and the screening of clonal cell populations are time- and thus cost-intensive. To overcome these limitations, expression cassettes were embedded into transposon-derived donor vectors. Upon the co-transfection with transposase-encoding constructs, elevated vector copy numbers stably integrated into the genomes of the host cells are readily achieved facilitating under stringent selection pressure the establishment of cell
\end{abstract}

N. Tschorn $\cdot$ K. Berg $\cdot$ J. Stitz $(\bowtie)$

Research Group Pharmaceutical Biotechnology, TH Köln - University of Applied Sciences, Chempark Leverkusen E28, Kaiser-Wilhelm-Allee, 51368 Leverkusen, Germany e-mail: joern.stitz@th-koeln.de

N. Tschorn

Institute of Technical Chemistry, Leibniz University

Hannover, Hannover, Germany

K. Berg

Research Group Translational Hepatology and Stem Cell Biology, Cluster of Excellence REBIRTH, Department of Gastroenterology, Hepatology, and Endocrinology,

Hannover Medical School, Hannover, Germany pools characterized by sustained and high-yield recombinant protein production. Here, we discuss some aspects of transposon vector technologies, which render these vectors promising candidates for their further utilization in the production of biologics.

Keywords Mammalian cells $\cdot$ piggyBac Protein production · Sleeping Beauty · Transposon vector

\section{Introduction}

With the growing demand for biotherapeutics at highest quality standards, mammalian cells are increasingly used for production. In 2018, 84\% of the marketed biotechnologically produced drugs were generated using mammalian cells. The vast majority of these biologics are therapeutic monoclonal antibodies produced in Chinese hamster ovary (CHO) cells (Walsh 2018).

Recombinant mammalian protein producer cell lines are not only required for the final industrial scale production of proteins of interest (POIs). They are already needed in early phases of drug discovery and development. POIs are produced at research laboratory-scale to facilitate their biochemical and biophysical characterization followed by preclinical trials in small animal models in vivo. The classical approach to establish recombinant cell lines uses circular plasmid 
DNA for stable transfection (Manceur et al. 2017). Although a wide range of transfection methods and reagents are available, some host cells show low transfectability. Even if the transient transfection efficiency-i.e. the epichromosomal cellular uptake of plasmids-is sufficient, the stable integration of linearized plasmid DNA into the host cell genome is a rare event. Depending on the host cell type, the donor organism and the transfection protocol used, most stably transfected cells only harbor low vector copy numbers (VCN) ranging from single to about five plasmid molecules randomly integrated into the host cell genome (Chusainow et al. 2009; Kolacsek et al. 2014). The integrated plasmid sequences do not only contain the expression cassette entailing a promoter/ enhancer required to drive the expression of the gene of interest (GOI) encoding the POI and a polyadenylation signal $(\mathrm{p}(\mathrm{A}))$, but also long bacteria-derived sequences. At least an origin of replication (ori) and an antibiotic-resistance gene allowing for the selection and subsequent amplification of the plasmid in transformed bacteria are required. These bacterial sequences are recognized as foreign and targeted by the methylation machinery in mammalian cells. This results in silencing of proximate eukaryotic or viral promoter/enhancer driving the expression of the GOI (Riu et al. 2007) and can consequently prevent sustained high-level POI production. Typically, polyclonal or pooled cell populations do not produce satisfying POI yields. Thus, the screening of hundreds or even thousands of cell clones to identify a protein producer cell demonstrating efficient, stable and sustained expression levels of POI is indispensable (Wang et al. 2018). In summary, using stable transfection, all aforementioned limitations contribute to the time-consuming and cost-intensive processes to establish protein producer cells. Novel vector technologies are required to accelerate the generation of transgenic cells at early drug development stages. Vector systems derived from transposons were developed and further improved in the past 15 years allowing the rapid establishment of stable recombinant mammalian cell pools for the high-yield production of biologics.

\section{DNA transposon biology and host cell interaction}

DNA transposons are fossil mobile DNA elements. A wide range of individual DNA transposons from different families and donor organisms were characterized in detail over the last three decades e.g. Tol2 originating from medeka fish, Sleeping Beauty synthetic sequences derived from transposons found in the white cloud minnow, atlantic salmon and rainbow trout - and piggyBac isolated from the cabbage looper moth (Fraser et al. 1996; Ivics et al. 1997; Kawakami et al. 1998). All DNA transposons are composed of a transposase gene and flanking inverted terminal repeats (ITRs; Muñoz-López and GarcíaPérez 2010). The enzyme transposase recognizes specific short target sequences, called directed repeats (DRs) located in the ITRs. Upon binding, the transposase cuts out the transposon sequence from the surrounding genomic DNA of the host cell. The formed complex consisting of the mobilized transposon DNA fragment and the still bound transposases is now able to change its position to a new location in the cell genome. The transposases open the genomic DNA backbone at the new locus and insert the transposon fragment. The ligation of the open DNA ends is mediated by cellular key factors of the nonhomologous end joining pathway (NHEJ) within the double strand break (DSB) repair system (Mátés et al. 2007). Thus, this so called transposition uses a cutand-paste mechanism.

The examination of the sequences targeted by the respective transposases for re-integration into the genomic DNA of the host cell revealed differences between various transposons. While Tol2 of the $h A T$ family could not be shown to prefer a specific sequence, members of the Tcl/mariner family like Sleeping Beauty (SB), Frog Prince and Minos as well as piggyBac ( $\mathrm{PB}$; superfamily $\mathrm{PB}$ ) clearly favor defined insertion motifs. With the dinucleotide TA for Tc1/mariner transposons and the four-nucleotide motif TTAA for PB, these target sequences are very short, and thus would allow close- to-random integration over the entire host cell genome (Grabundzija et al. 2010). This assumption was further supported by the findings that Tol2, SB and PB did not show any preference for specific host cell chromosomes. Tc1/mariner transposons including SB were demonstrated to perform close-to-random integration. Although not very pronounced, there seems to be a weak bias in mammalian cells towards the insertion into transcribed regions and their regulatory sequences located upstream (Yant et al. 2005; Huang et al. 2010; Gogol-Döring et al. 2016). In contrast, Tol2 and PB 
favor certain specific genomic regions. Both, Tol2 and $\mathrm{PB}$, insert mostly upstream and in close proximity to transcriptional start sites (TSSs), CpG-islands and DNase I hypersensitive sites (Huang et al. 2010). For PB it was recently shown (Gogol-Döring et al. 2016) that the cellular BET proteins interact with the transposase and guide the accumulation of insertions to TSSs. In this regard, PB shows a high similarity to the $\gamma$-retrovirus murine leukemia virus (MLV; Wu et al. 2003; de Jong et al. 2014; Gogol-Döring et al. 2016).

Only a few cellular proteins interacting with the transposase have been described to date. In a yeast two-hybrid screen the transcription factor Myc-interacting protein zinc finger 1 (Miz1) was identified to interact with SB transposase (Walisko et al. 2006). As a result the expression of cyclin D is down-regulated in transgenic human cells leading to a temporary arrest in cell cycle phase $G_{1}$. Integration into the host cell genome appears to be more efficient during a prolonged $\mathrm{G}_{1}$ phase. The DNA-bending high mobility group protein 1 (HMGB1) was shown to be crucial to facilitate efficient transposition. While transposition was largely limited in HMGB1-deficient murine cells, this restriction was abrogated by transient recombinant over-expression of HMGB1 and partially overcome by HMGB2. It is assumed, that at least HGMB1 serves as a co-factor for binding of the transposase to the target DR sequences in the ITRs, and thus supporting the formation of the synaptic transposaseDNA complex during transposition (Zayed et al. 2003). In contrast, transposition of PB appears to be largely cell factor independent as it can be experimentally reconstituted in vitro using purified PB transposase and DNA elements (Burnight et al. 2012). Like retroviruses, SB as well as PB seem to exploit the cellular barrier to autointegration factor (BAF) to promote transposon integration into the host genome at high efficiencies by preventing autointegration (Wang et al. 2014).

\section{DNA transposon vectors}

As illustrated in Fig. 1, in a two-component DNA transposon-derived vector system the transposase gene and the ITRs are separated onto two different plasmids. The transposase construct minimally entails a suitable promoter active in the desired host cell, the sequence encoding the transposase and a 3'-located
$\mathrm{p}(\mathrm{A})$. The donor or transposon vector encompasses an expression cassette with the GOI flanked by the ITRs. Upon co-transfection of target cells with both plasmids, the transposase is expressed and cuts out the GOI expression cassette framed by the ITRs from the plasmid backbone. The subsequent stable insertion of the transposon vector into the genome concludes the transposition process (Ivics et al. 1997). In contrast to transgenic cells established by classical stable transfection using plasmids, the integrated transposon vectors do not contain any bacterial sequences originating from the plasmid vector backbone. Consequently, silencing of the promoter driving GOI expression should presumably occur at much lower frequency (Riu et al. 2007). Amongst other features, this renders transposon vectors attractive tools for the establishment of recombinant protein producer cells.

Vector systems derived from SB and PB are most frequently used for biotechnological applications. However, the first generation of transposon vectors derived from SB was characterized by low transposition efficiencies (Ivics et al. 1997). The stepwise optimization of the SB transposase by the introduction of accumulating mutations led in a pioneering study to the evolved enzyme SB100X revealing a 100-fold improved activity as compared to the wild-type protein (Mátés et al. 2009; Voigt et al. 2016). The transposase of $\mathrm{PB}$, namely $\mathrm{mPB}$, was first adapted to mediate 20-fold enhanced transposition efficiency in mammalian cells employing codon optimization (Cadiñanos and Bradley 2007; Liang et al. 2009). Following the example of improving transposase activity by means of molecular evolution (Mátés et al. 2009), the mPB enzyme was further advanced. The resultant hyPB was demonstrated to mediate 10-fold enhanced transposition activity in mammalian cells as compared to mPB (Yusa et al. 2011). Cui and co-workers (Cui et al. 2002) described the optimization of the ITR sequences of SB transposon vectors leading to a four-fold increase of transposition events in human HeLa cells. Later attempts to improve transposition efficiencies of SB vectors by the introduction of additional point mutations within the ITRs did unfortunately not lead to further improvements (Scheuermann et al. 2019).

The achieved transgenic rate-i.e. the percentage of stably genetically modified cells as a result of stable integration of the donor vector into the host cell genome-using SB and PB two-component vector 
Transposase construct

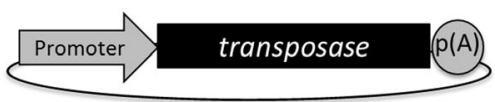

Transposon vector (donor)

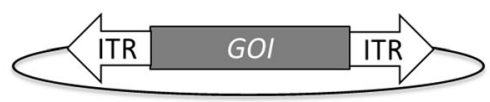

Co-Transfection
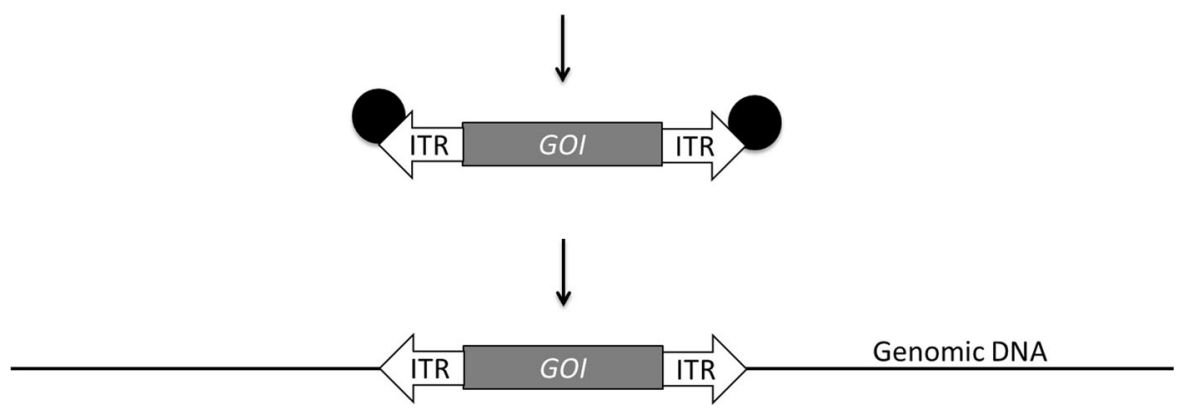

Fig. 1 Two-component transposon vector systems consist of a transposase construct minimally encompassing a promoter/ enhancer upstream of the transposase coding region and a polyadenylation signal $(\mathrm{p}(\mathrm{A}))$. The transposon or donor vector contains the gene of interest (GOI) flanked by the inverted

systems obviously depends on the transfectability of the desired target cell and the transfection protocol employed, which may require individual optimization. The efficiency of transposition can be divided into three different subsequent events: (i) the excision of the transposon vector from the plasmid backbone, (ii) the overall stable transgenic rate and (iii) the average VCN per cell (Kolacsek et al. 2014). The transposition efficiencies observed in different cell types are highly variable (Izsvák et al. 2000; Troyanovsky et al. 2016). Besides the amount of plasmid DNA transfected per target cell count (high versus low dose), optimization of the transposition rate and VCN per cell can be improved by determining the optimal ratio of transposase construct to transposon vector (Grabundzija et al. 2010). For the utilization of SB-derived vector systems, it has to be emphasized that an excess of transposase hampers efficient transposition-a phenomenon termed overexpression inhibition (OPI). It was hypothesized that a high concentration of transposase saturates the target DR sequences in the ITRs slowing synapsis formation of transposon ends (Liu and Chalmers 2014). Consequently, the optimal SB transposase construct to donor ratio, depending on the genetic design of the expression cassettes, ranges in most cell types from $1 / 5$ to $1 / 30$. PB transposase does not suffer from OPI (Wilson et al. 2007). Nevertheless, terminal repeats (ITRs). Upon co-transfection into suitable host cells, the transposase expressed in trans binds to the ITRs and cuts out the transposon vector fragment from the bacterial plasmid backbone and mediates the integration into the cell genome using a cut-and-paste mechanism

also for PB systems the optimal balance of vector components has to be examined for every target cell aiming to achieve the highest transgenic rate.

Higher transgenic rates are generally achieved using larger amounts of transposon vector molecules in high dose transfection protocols (e.g. $>500 \mathrm{ng}$ DNA per $1 \times 10^{5}$ cells). Depending on the host cell line, its transfectability and its assistance in transposition, about 10 to $30 \%$ of the transfected cells are stably modified. The DNA dosage also influences the integrated copy numbers per cell. Using low dose approaches $\left(15-50 \mathrm{ng}\right.$ per $1 \times 10^{5}$ cells) the vast majority of transgenic cells show single vector integrations. Here, usually 1 to $10 \%$ of the transfected cells reveal stable vector integration. In contrast and upon high dose transfection, $\mathrm{PB}$ transposon vectors reach single to single-digit number of vector insertions per cell, respectively. However, SB100X facilitates up to 40 integrations under these conditions (Grabundzija et al. 2010). The high vector copy numbers per cell make SB vectors attractive for the establishment of stable producer cell lines. However, PB vectors seem to have the advantage of targeting favorable sites close to TSSs resulting in higher levels of transgene expression. Besides the high transposition rates achieved with both transposon vector systems, SB and $\mathrm{PB}$ qualify for a wide range of biotechnological 
applications due to their considerable high cargo capacity. SB vectors were reported to be instrumental in gene transduction carrying payloads of up to $6 \mathrm{~kb}$. Larger transgene cassettes lead to declining transposition frequencies (Izsvák et al. 2000; Rostovskaya et al. 2012). However, SB and PB vectors were demonstrated to mediate stable transgene transfer of even larger DNA molecules such as artificial bacterial chromosomes (BACs) with sizes of up to impressive $200 \mathrm{~kb}$ outperforming retroviral vectors with maximum cargo capacities of about $6 \mathrm{~kb}$ (Li et al. 2011; Rostovskaya et al. 2012).

Transposon vectors for the accelerated establishment of mammalian protein producer cell pools

Due to their ability to stably transduce genetic cargo into a variety of mammalian cell types, transposon vectors, particularly derived from $\mathrm{SB}$ and $\mathrm{PB}$, provide a toolbox for many applications. These include the generation of transgenic animals, the development of gene knock-out screens in gene function discovery, the establishment of inducible pluripotent stem cells (iPSCs) and the utilization in somatic gene therapy (Di Matteo et al. 2012; Yusa 2015; Narayanavari et al. 2017; Tipanee et al. 2017). In these fields, transposon vectors are increasingly used as alternatives to retroviral vector-mediated gene transfer (Vargas et al. 2016).

The generation of polyclonal pools of genetically modified mammalian cells for the purpose of recombinant protein production was first demonstrated using MLV and HIV-1 vectors mediating gene transduction (Oberbek et al. 2011; Stitz 2011; Elegheert et al. 2018). These approaches capitalized on the stable integration of multiple vector copies per cell and the sustained expression of the transgenes as a result of the favored insertion sites located in the proximity of transcriptional start sites and active cellular transcription units (Craigie and Bushman 2014; Gogol-Döring et al. 2016). The productivity of the recombinant cell pools and cell clones established upon viral vectormediated gene transduction was remarkable. However, the utilization of viral vector technology requires (i) the establishment of stable or transient viral packaging cells, upon co-expression of at least three different constructs, namely, the transfer vector harboring the transgene of choice, a packaging construct minimally encompassing the structural genes gag and pol encoding for the viral core proteins and enzymes and an envelope construct enabling the expression of the Env proteins facilitating vector particle cell entry. (ii) The subsequent titration of produced vector particle preparations in suitable susceptible target cells has to be conducted. (iii) In case vector particles with a tropism for human cells or pantropic vectors pseudotyped with the G-protein of vesicular stomatitis virus (VSV-G) are used, a biosafety level 2 laboratory (BSL-2) is indispensable. In summary, the complexity of viral vector production and characterization reduces the attractiveness of retrovirus technology for the establishment of transgenic cell pools for protein production.

The utilization of transposon vectors is comparably convenient and straightforward as illustrated in Fig. 2. The required optimization of transfection protocols and the assessment of the optimal transposase construct to transposon vector ratio for the host cell of choice are standard practices easily established in any laboratory and are quickly performed by experienced staff. Usually, the generated recombinant mammalian cells are classified as genetically modified organisms of BSL-1, provided that the mobilized payload is not hazardous itself e.g. oncogenes. $\mathrm{PB}$ and $\mathrm{SB}$ vector systems are both instrumental in the rapid establishment of transgenic cells in vitro. Multiple stable insertions of vectors in the host cell genome are readily achieved. With a possible payload of far more than 6 $\mathrm{kb}$, both transposon vector systems exceed the capacity requirements for the purpose of protein production. Even two protein encoding expression cassettes in cis are easily mobilized, e.g. for the co-production of heavy and light chains of monoclonal antibodies (mAbs; Ahmadi et al. 2017).

Matasci et al. (2011) were the first to use PB vectors to establish pools of $\mathrm{CHO}$ cells producing tumor necrosis factor receptor (TNFR) fused to the Fcfragment of human immunoglobulin G1 (IgG1). The bicistronic donor vector entailed a cytomegalovirus promoter/enhancer $\left(\mathrm{P}_{\mathrm{CMV}}\right)$ driving the expression of the fusion protein and a herpes simplex virus thymidine kinase promoter $\left(\mathrm{P}_{\mathrm{HSV}-\mathrm{TK}}\right)$ coupled to a pac gene mediating resistance against puromycin. Using a $\mathrm{mPB}$ transposase expression construct to donor vector ratio of 1:9, transgenic cells were established upon co-transfection. One day post transfection, cells were subjected to selection by expansion 

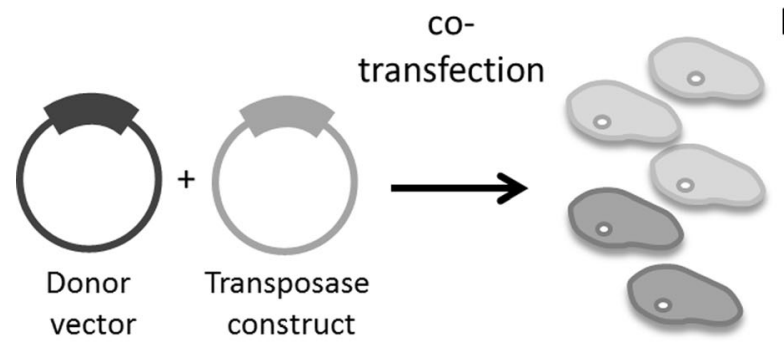

host cells

Fig. 2 Rapid establishment of protein producer cells using a two-component transposon vector system by co-transfection of the donor vector and the transposase construct into host cells.

in the presence of puromycin at a concentration of 10 and $50 \mu \mathrm{g} / \mathrm{ml}$. Both resultant stable cell pools$\mathrm{PB}(10)$ and $\mathrm{PB}(50)$, indicating the selection pressure applied-facilitated considerable product yields of 42 and $50 \mathrm{mg} / \mathrm{l} \mathrm{TNFR:Fc}$, respectively. A number of cell clones were isolated from both pools and analyzed for their productivity. While more than $34 \%$ of the $\mathrm{PB}(50)$-derived clones revealed a productivity reaching 50 to $100 \mathrm{mg} / \mathrm{l}$, only $28.6 \%$ of the clones originating from the parental $\mathrm{PB}(10)$ pool were as productive. This difference in cell productivity was even more visible for yields between 25 and $50 \mathrm{mg} / \mathrm{l}$ with $55.8 \%$ of all $\mathrm{PB}(50)$-derived clones and only again $28.6 \%$ of $\mathrm{PB}(10)$ cell clones. Only less than $10 \%$ of the $\mathrm{PB}(50)$ cell clones produced less than $25 \mathrm{mg} / \mathrm{l}$. In contrast, $40 \%$ of $\mathrm{PB}(10)$ clones were significantly less productive than the parental pool. As expected, enhanced productivity correlated with higher VCN per cell ranging from an average of three copies for the least productive clones up to six copies for the best performing ones. In conclusion, this demonstrated the rapid establishment of cell pools with advanced productivity employing $\mathrm{PB}$ vectors and very stringent selection. Noteworthy, cell productivity of pools and clones was stable over a period of three months in the absence of selection (Matasci et al. 2011).

In 2016, the research team led by Dr. Wurm used the above described expression cassettes in transposon vectors derived from Tol2, SB and again PB to compare the three vector systems for their potential to establish $\mathrm{CHO}$ producer cell pools and clones (Balasubramanian et al. 2016a). The optimal donor to transposase construct ratio for each vector system using $\mathrm{mTol} 2, \mathrm{mPB}$ and $\mathrm{SB} 100 \mathrm{X}$ transposases was assessed. Tol2 vectors showed dramatically lower

\section{high selection high-yield \\ pressure \\ product}

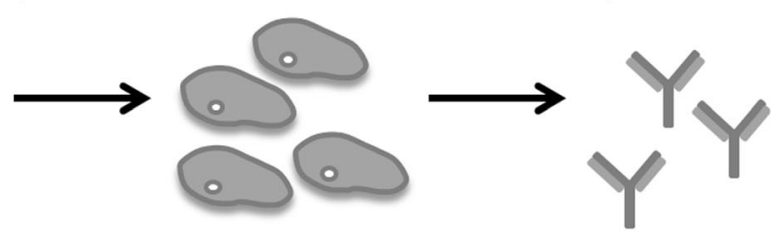

producer cell pool

One or two days post transfection, selection pressure can be applied to generate a high-yield producer cell pool

transposition efficiencies as compared to SB and PB. In fact, even with the best performing donor to transposase construct ratio employed, at least over $60 \%$ of the inserted Tol 2 vectors were demonstrated to be a result of stable transfection rather than transposition. Consequently, and in the absence of selection pressure, cell pools established with $\mathrm{PB}$ and SB vectors generated significantly higher transgenic rates of about $20 \%$ stably modified cell populations as compared to less than 5\% using the Tol2-derived system. In addition, SB and $\mathrm{PB}$ vectors reached more than three-fold higher transgene expression levels than Tol2 vectors. However, and upon application of a low selection pressure (10 $\mu \mathrm{g}$ puromycin/ml) for ten days, pools of cells were established reaching productivities ranging from $80 \mathrm{mg} / \mathrm{l}$ of TNFR:Fc using Tol 2 vectors to $95 \mathrm{mg} / \mathrm{l}$ for PB and SB vectors. On average, ninefold higher yields were obtained using transposasemediated gene transfer as compared to conventional stable transfection of plasmids. In 14-day fed-batch cultures of pools, TNFR:Fc levels of up to $900 \mathrm{mg} / \mathrm{l}$ were achieved. Over a period of three months in the absence of selection pressure, productivity decreased to approximately $50 \%$ of the initial yields for all pools generated with the three vector systems. This underscored the necessity of stringent selection to establish sustained high-yield expression.

$\mathrm{PB}$ vectors were also utilized to establish $\mathrm{CHO}$ cell pools for the production of monoclonal antibodies. The expression of heavy and light chain was driven by a $\mathrm{P}_{\mathrm{CMV}}$ whereas a $\mathrm{SV} 40$ promoter mediated the expression of glutamine synthetase (GS). These expression cassettes present on one donor vector were flanked by insulator sequences to minimize posttranspositional silencing. Stable recombinant cell 
pools cultivated in shaker flasks were established producing four different mAbs. Yields of 2.3 to up to remarkable $7.6 \mathrm{~g} / \mathrm{l}$ were reported (Rajendra et al. 2016). Unfortunately, the identity of the produced antibodies was not disclosed. The high productivities of the cell pools were shown to originate from up to seven VCN per cell leading to high expression levels of mRNA. Most importantly, the cell pools revealed a very high homogeneity resulting from highly productive clones composing the vast majority of the population. The scale-up from shaker flasks to a 361 bioreactor delivered yields of $4.7 \mathrm{~g} / \mathrm{l}$ for one of the monoclonal antibodies (Rajendra et al. 2017a). CHO pools established using $\mathrm{PB}$ vector-mediated gene transduction produced mAbs of the same quality as compared to mAbs harvested from clonal producer cell lines generated by stable transfection. This finding was also confirmed in a second study conducting capillary electrophoresis-sodium dodecyl sulfate (CESDS), glycan analysis, analytical size-exclusion chromatography (aSEC) and peptide mapping analysis using liquid chromatography and mass spectrometry (LCMS; Rajendra et al. 2017b).

High yields of multiple products can also be achieved by the generation of cell pools using simultaneous co-expression from multiple individual transposon vectors upon co-transfection with a transposase construct. The team around Balasubramanian (Balasubramanian et al. 2016b) demonstrated the establishment of $\mathrm{CHO}$ cell pools producing three model proteins, namely, enhanced green fluorescent protein (EGFP), secreted alkaline phosphatase (SEAP) and a monoclonal antibody. Not surprisingly, the productivity of the pools was superior when each individual transgene encompassing transposon vector carried a different selectable marker allowing for the application of three separate selection pressures at the same time. Accordingly, we recently reported on the rapid establishment of highly efficient viral packaging cell lines (VPCs) using SB-derived transposon vectors in human HT-1080 fibrosarcoma cells (Berg et al. 2019). All three vector components required-the packaging and $e n v$-construct and the transfer vector as well-were co-transfected with the transposase construct and allowed for subsequent triple-selection. Within only three weeks, VPCs were established reaching vector particle yields of over $1.0 \times 10^{6}$ transducing units per $\mathrm{ml}(\mathrm{TU} / \mathrm{ml})$. In contrast, VPCs that were generated by conventional stable plasmid transfection achieved 20-fold lower titers and required an extended establishment time of three months.

The previously mentioned findings demonstrate the utility of transposon vectors for the future generation of cell pools to rapidly produce second generation biologics composed of multiple components. Examples for these complex biologics are viral vector particles for somatic gene therapy and enveloped virus-like particle (VLP) vaccines displaying single or multiple target antigens at high density on their surface. There is a demand in the pharmaceutical industry for accelerated producer cell line development without lowering product yields or compromising product quality to maintain the provision of biologics at economically affordable prices to the growing market.

\section{Conclusions and outlook}

Amongst others, transposon vector systems derived from Sleeping Beauty and piggyBac are most frequently used for biotechnological applications. Transposases were optimized and donor vectors further developed enabling the rapid establishment of highly productive recombinant cell pools. Upon a brief optimization of the co-transfection method and the donor vector to transposase construct ratio, a wide range of host cells is susceptible to these relatively new vector systems. The technology capitalizes on the efficient stable integration of multiple transgene expression cassettes per cell. Using the industry gold standard $\mathrm{CHO}$ as host cells, transgenic rates of $20 \%$ are readily achieved. Antibiotic resistance marker genes coupled to the transgene of choice facilitate the stringent selection required to establish highly productive pools of cell clones in a short time. Transposon vectors were shown to overcome the limitations of conventional stable plasmid transfection and will thus prove their utility and value for the future development of novel biologics and their industrial scale production.

However, the development of these vectors is still in an early pioneering stage. Most importantly, the vector design can certainly be further improved. Some advancement was already achieved in enhancing expression of transgenes by insertion of matrix attachment regions (MARs; Ley et al. 2013). To minimize gene silencing, the utilization of flanking 
cHS4 DNA insulators was instrumental (Sharma et al. 2012). Transposon vectors encompassing inducible transgene expression cassettes for the production of cytotoxic proteins were generated (Kowarz et al. 2015; Michael and Nagy 2018). To avoid the use of antibiotics during transgenic cell selection and product manufacturing, vectors were designed for the establishment of cell pools upon chemically induced dimerization of growth factor receptors (Kacherovsky et al. 2012). Novel panels of transposon vectors will have to be tailored combining multiple genetic elements and vector components to further enhance expression levels and to meet specific requirements of future industrial production scenarios.

Acknowledgements Open Access funding provided by Projekt DEAL. This work was supported by the German Federal Ministry of Education and Research, funding program Forschung an Fachhochschulen (contract number 13FH242PX6) to JS.

Open Access This article is licensed under a Creative Commons Attribution 4.0 International License, which permits use, sharing, adaptation, distribution and reproduction in any medium or format, as long as you give appropriate credit to the original author(s) and the source, provide a link to the Creative Commons licence, and indicate if changes were made. The images or other third party material in this article are included in the article's Creative Commons licence, unless indicated otherwise in a credit line to the material. If material is not included in the article's Creative Commons licence and your intended use is not permitted by statutory regulation or exceeds the permitted use, you will need to obtain permission directly from the copyright holder. To view a copy of this licence, visit http://creativecommons.org/licenses/by/4.0/.

\section{References}

Ahmadi S, Davami F, Davoudi N, Nematpour F, Ahmadi M, Ebadat S, Azadmanesh K, Barkhordari F, Mahboudi F (2017) Monoclonal antibodies expression improvement in $\mathrm{CHO}$ cells by PiggyBac transposition regarding vectors ratios and design. PLoS ONE 12:e0179902. https://doi.org/ 10.1371/journal.pone.0179902

Balasubramanian S, Rajendra Y, Baldi L, Hacker DL, Wurm FM (2016a) Comparison of three transposons for the generation of highly productive recombinant $\mathrm{CHO}$ cell pools and cell lines. Biotechnol Bioeng 113:1234-1243. https:// doi.org/10.1002/bit.25888

Balasubramanian S, Wurm FM, Hacker DL (2016b) Multigene expression in stable $\mathrm{CHO}$ cell pools generated with the piggyBac transposon system. Biotechnol Prog 32:1308-1317. https://doi.org/10.1002/btpr.2319
Berg K, Schäfer VN, Bartnicki N, Eggenschwiler R, Cantz T, Stitz J (2019) Rapid establishment of stable retroviral packaging cells and recombinant susceptible target cell lines employing novel transposon vectors derived from Sleeping Beauty. Virology 531:40-47. https://doi.org/10. 1016/j.virol.2019.02.014

Burnight ER, Staber JM, Korsakov P, Li X, Brett BT, Scheetz TE, Craig NL, McCray PB (2012) A Hyperactive Transposase Promotes Persistent Gene Transfer of a piggyBac DNA Transposon. Mol Ther Nucleic Acids 1:e50. https:// doi.org/10.1038/mtna.2012.12

Cadiñanos J, Bradley A (2007) Generation of an inducible and optimized piggyBac transposon system. Nucleic Acids Res 35:e87. https://doi.org/10.1093/nar/gkm446

Chusainow J, Yang YS, Yeo JHM, Ton PC, Asvadi P, Wong NSC, Yap MGS (2009) A study of monoclonal antibodyproducing $\mathrm{CHO}$ cell lines: What makes a stable high producer? Biotechnol Bioeng 102:1182-1196. https://doi.org/ 10.1002/bit.22158

Craigie R, Bushman FD (2014) Host Factors in Retroviral Integration and the Selection of Integration Target Sites. Microbiol Spectr 2:1035-1050. https://doi.org/10.1128/ microbiolspec.MDNA3-0026-2014

Cui Z, Geurts AM, Liu G, Kaufman CD, Hackett PB (2002) Structure-function analysis of the inverted terminal repeats of the sleeping beauty transposon. J Mol Biol 318:1221-1235. https://doi.org/10.1016/S00222836(02)00237-1

de Jong J, Akhtar W, Badhai J, Rust AG, Rad R, Hilkens J, Berns A, van Lohuizen M, Wessels LFA, de Ridder J (2014) Chromatin landscapes of retroviral and transposon integration profiles. PLoS Genet 10:e1004250. https://doi.org/ 10.1371/journal.pgen. 1004250

Di Matteo M, Belay E, Chuah MK, VandenDriessche T (2012) Recent developments in transposon-mediated gene therapy. Expert Opin Biol Ther 12:841-858. https://doi.org/10. 1517/14712598.2012.684875

Elegheert J, Behiels E, Bishop B, Scott S, Woolley RE, Griffiths SC, Byrne EFX, Chang VT, Stuart DI, Jones EY, Siebold C, Aricescu AR (2018) Lentiviral transduction of mammalian cells for fast, scalable and high-level production of soluble and membrane proteins. Nat Protoc 13:2991-3017. https://doi.org/10.1038/s41596-018-0075-9

Fraser MJ, Ciszczon T, Elick T, Bauser C (1996) Precise excision of TTAA-specific lepidopteran transposons piggyBac (IFP2) and tagalong (TFP3) from the baculovirus genome in cell lines from two species of Lepidoptera. Insect Mol Biol 5:141-151. https://doi.org/10.1111/j.1365-2583. 1996.tb00048.x

Gogol-Döring A, Ammar I, Gupta S, Bunse M, Miskey C, Chen W, Uckert W, Schulz TF, Izsvák Z, Ivics Z (2016) Genome-wide Profiling Reveals Remarkable Parallels Between Insertion Site Selection Properties of the MLV Retrovirus and the piggyBac Transposon in Primary Human CD4(+) T Cells. Mol Ther 24:592-606. https://doi.org/10.1038/mt. 2016.11

Grabundzija I, Irgang M, Mátés L, Belay E, Matrai J, GogolDöring A, Kawakami K, Chen W, Ruiz P, Chuah MKL, VandenDriessche T, Izsvák Z, Ivics Z (2010) Comparative analysis of transposable element vector systems in human 
cells. Mol Ther 18:1200-1209. https://doi.org/10.1038/mt. 2010.47

Huang X, Guo H, Tammana S, Jung Y-C, Mellgren E, Bassi P, Cao Q, Tu ZJ, Kim YC, Ekker SC, Wu X, Wang SM, Zhou $X$ (2010) Gene transfer efficiency and genome-wide integration profiling of Sleeping Beauty, Tol2, and piggyBac transposons in human primary $\mathrm{T}$ cells. Mol Ther 18:1803-1813. https://doi.org/10.1038/mt.2010.141

Ivics Z, Hackett PB, Plasterk RH, Izsvák Z (1997) Molecular reconstruction of Sleeping Beauty, a Tc1-like transposon from fish, and its transposition in human cells. Cell 91:501-510. https://doi.org/10.1016/s00928674(00)80436-5

Izsvák Z, Ivics Z, Plasterk RH (2000) Sleeping Beauty, a wide host-range transposon vector for genetic transformation in vertebrates 1 1Edited by J. Karn. J Mol Biol 302:93-102. https://doi.org/10.1006/jmbi.2000.4047

Kacherovsky N, Harkey MA, Blau CA, Giachelli CM, Pun SH (2012) Combination of Sleeping Beauty transposition and chemically induced dimerization selection for robust production of engineered cells. Nucleic Acids Res 40:e85e85. https://doi.org/10.1093/nar/gks213

Kawakami K, Koga A, Hori H, Shima A (1998) Excision of the Tol2 transposable element of the medaka fish, Oryzias latipes, in zebrafish, Danio rerio. Gene 225:17-22. https:// doi.org/10.1016/S0378-1119(98)00537-X

Kolacsek O, Erdei Z, Apáti A, Sándor S, Izsvák Z, Ivics Z, Sarkadi B, Orbán TI (2014) Excision Efficiency Is Not Strongly Coupled to Transgenic Rate: Cell Type-Dependent Transposition Efficiency of Sleeping Beauty and piggyBac DNA Transposons. Hum Gene Ther Methods 25:241-252. https://doi.org/10.1089/hgtb.2013.149

Kowarz E, Löscher D, Marschalek R (2015) Optimized Sleeping Beauty transposons rapidly generate stable transgenic cell lines. Biotechnol J 10:647-653. https://doi.org/10.1002/ biot. 201400821

Ley D, Harraghy N, Le Fourn V, Bire S, Girod P-A, Regamey A, Rouleux-Bonnin F, Bigot Y, Mermod N (2013) MAR elements and transposons for improved transgene integration and expression. PLoS ONE 8:e62784. https://doi.org/ 10.1371/journal.pone.0062784

Li MA, Turner DJ, Ning Z, Yusa K, Liang Q, Eckert S, Rad L, Fitzgerald TW, Craig NL, Bradley A (2011) Mobilization of giant piggyBac transposons in the mouse genome. Nucleic Acids Res 39:e148-e148. https://doi.org/10.1093/ nar/gkr764

Liang Q, Kong J, Stalker J, Bradley A (2009) Chromosomal mobilization and reintegration of Sleeping Beauty and PiggyBac transposons. Genesis 47:404-408. https://doi. org/10.1002/dvg.20508

Liu D, Chalmers R (2014) Hyperactive mariner transposons are created by mutations that disrupt allosterism and increase the rate of transposon end synapsis. Nucleic Acids Res 42:2637-2645. https://doi.org/10.1093/nar/gkt1218

Manceur AP, Kim H, Misic V, Andreev N, Dorion-Thibaudeau J, Lanthier S, Bernier A, Tremblay S, Gélinas A-M, Broussau S, Gilbert R, Ansorge S (2017) Scalable lentiviral vector production using stable HEK293SF producer cell lines. Hum Gene Ther Methods 28:330-339. https://doi. org/10.1089/hgtb.2017.086
Matasci M, Baldi L, Hacker DL, Wurm FM (2011) The PiggyBac transposon enhances the frequency of $\mathrm{CHO}$ stable cell line generation and yields recombinant lines with superior productivity and stability. Biotechnol Bioeng 108:2141-2150. https://doi.org/10.1002/bit.23167

Mátés L, Izsvák Z, Ivics Z (2007) Technology transfer from worms and flies to vertebrates: transposition-based genome manipulations and their future perspectives. Genome Biol 8(Suppl 1):S1. https://doi.org/10.1186/gb-2007-8-s1-s1

Mátés L, Chuah MKL, Belay E, Jerchow B, Manoj N, AcostaSanchez A, Grzela DP, Schmitt A, Becker K, Matrai J, Ma L, Samara-Kuko E, Gysemans C, Pryputniewicz D, Miskey C, Fletcher B, VandenDriessche T, Ivics Z, Izsvák Z (2009) Molecular evolution of a novel hyperactive Sleeping Beauty transposase enables robust stable gene transfer in vertebrates. Nat Genet 41:753-761. https://doi.org/10. 1038/ng.343

Michael IP, Nagy A (2018) Inducible Protein Production in 293 Cells Using the piggyBac Transposon System. Methods Mol Biol 1850:57-68. https://doi.org/10.1007/978-14939-8730-6_5

Muñoz-López M, García-Pérez JL (2010) DNA transposons: nature and applications in genomics. Curr Genomics 11:115-128. 138920210790886871

Narayanavari SA, Chilkunda SS, Ivics Z, Izsvák Z (2017) Sleeping Beauty transposition: from biology to applications. Crit Rev Biochem Mol Biol 52:18-44. https://doi. org/10.1080/10409238.2016.1237935

Oberbek A, Matasci M, Hacker DL, Wurm FM (2011) Generation of stable, high-producing cho cell lines by lentiviral vector-mediated gene transfer in serum-free suspension culture. Biotechnol Bioeng 108:600-610. https://doi.org/ 10.1002/bit.22968

Rajendra Y, Peery RB, Barnard GC (2016) Generation of stable Chinese hamster ovary pools yielding antibody titers of up to $7.6 \mathrm{~g} / \mathrm{L}$ using the piggyBac transposon system. Biotechnol Prog 32:1301-1307. https://doi.org/10.1002/ btpr. 2307

Rajendra Y, Balasubramanian S, Peery RB, Swartling JR, McCracken NA, Norris DL, Frye CC, Barnard GC (2017a) Bioreactor scale up and protein product quality characterization of piggyBac transposon derived $\mathrm{CHO}$ pools. Biotechnol Prog 33:534-540. https://doi.org/10.1002/btpr. 2447

Rajendra Y, Balasubramanian S, McCracken NA, Norris DL, Lian Z, Schmitt MG, Frye CC, Barnard GC (2017b) Evaluation of piggyBac-mediated $\mathrm{CHO}$ pools to enable material generation to support GLP toxicology studies. Biotechnol Prog 33:1436-1448. https://doi.org/10.1002/ btpr.2495

Riu E, Chen Z-Y, Xu H, He C-Y, Kay MA (2007) Histone Modifications are Associated with the Persistence or Silencing of Vector-mediated Transgene Expression In Vivo. Mol Ther 15:1348-1355. https://doi.org/10.1038/ sj.mt.6300177

Rostovskaya M, Fu J, Obst M, Baer I, Weidlich S, Wang H, Smith AJH, Anastassiadis K, Stewart AF (2012) Transposon-mediated BAC transgenesis in human ES cells. Nucleic Acids Res 40:e150-e150. https://doi.org/10.1093/ nar/gks643 
Scheuermann B, Diem T, Ivics Z, Andrade-Navarro MA (2019) Evolution-guided evaluation of the inverted terminal repeats of the synthetic transposon Sleeping Beauty. Sci Rep 9:1171. https://doi.org/10.1038/s41598-018-38061-w

Sharma N, Hollensen AK, Bak RO, Staunstrup NH, Schrøder LD, Mikkelsen JG (2012) The Impact of cHS4 Insulators on DNA Transposon Vector Mobilization and Silencing in Retinal Pigment Epithelium Cells. PLoS One 7:e48421. https://doi.org/10.1371/journal.pone.0048421

Stitz J (2011) Retroviral vector particles and methods for their generation and use. WO/ 2011/061336 May 26

Tipanee J, VandenDriessche T, Chuah MK (2017) Transposons: Moving Forward from Preclinical Studies to Clinical Trials. Hum Gene Ther 28:1087-1104. https://doi.org/10. 1089/hum.2017.128

Troyanovsky B, Bitko V, Pastukh V, Fouty B, Solodushko V (2016) The functionality of minimal PiggyBac transposons in mammalian cells. Mol Ther - Nucleic Acids 5:e369. https://doi.org/10.1038/mtna.2016.76

Vargas JE, Chicaybam L, Stein RT, Tanuri A, Delgado-Cañedo A, Bonamino MH (2016) Retroviral vectors and transposons for stable gene therapy: advances, current challenges and perspectives. J Transl Med 14:288. https://doi. org/10.1186/s12967-016-1047-x

Voigt F, Wiedemann L, Zuliani C, Querques I, Sebe A, Mátés L, Izsvák Z, Ivics Z, Barabas O (2016) Sleeping Beauty transposase structure allows rational design of hyperactive variants for genetic engineering. Nat Commun 7:11126. https://doi.org/10.1038/ncomms11126

Walisko O, Izsvák Z, Szabó K, Kaufman CD, Herold S, Ivics Z (2006) Sleeping Beauty transposase modulates cell-cycle progression through interaction with Miz-1. Proc Natl Acad Sci USA 103:4062-4067. https://doi.org/10.1073/ pnas.0507683103

Walsh G (2018) Biopharmaceutical benchmarks 2018. Nat Biotechnol 36:1136-1145. https://doi.org/10.1038/nbt. 4305

Wang Y, Wang J, Devaraj A, Singh M, Jimenez Orgaz A, Chen J-X, Selbach M, Ivics Z, Izsvák Z (2014) Suicidal autointegration of sleeping beauty and PiggyBac transposons in eukaryotic Cells. PLoS Genet 10:e1004103. https://doi.org/10.1371/journal.pgen.1004103

Wang B, Albanetti T, Miro-Quesada G, Flack L, Li L, Klover J, Burson K, Evans K, Ivory W, Bowen M, Schoner R, Hawley-Nelson P (2018) High-throughput screening of antibody-expressing $\mathrm{CHO}$ clones using an automated shaken deep-well system. Biotechnol Prog 34:1460-1471. https://doi.org/10.1002/btpr.2721

Wilson MH, Coates CJ, George AL (2007) PiggyBac transposon-mediated gene transfer in human cells. Mol Ther 15:139-145. https://doi.org/10.1038/sj.mt.6300028

Wu X, Li Y, Crise B, Burgess SM (2003) Transcription start regions in the human genome are favored targets for MLV integration. Science 300:1749-1751. https://doi.org/10. 1126/science. 1083413

Yant SR, Wu X, Huang Y, Garrison B, Burgess SM, Kay MA (2005) High-Resolution Genome-Wide Mapping of Transposon Integration in Mammals. Mol Cell Biol 25:2085-2094. https://doi.org/10.1128/MCB.25.6.20852094.2005

Yusa K (2015) piggyBac Transposon. Microbiol Spectr 3:MDNA3-0028-2014. https://doi.org/10.1128/ microbiolspec.MDNA3-0028-2014

Yusa K, Zhou L, Li MA, Bradley A, Craig NL (2011) A hyperactive piggyBac transposase for mammalian applications. Proc Natl Acad Sci USA 108:1531-1536. https:// doi.org/10.1073/pnas.1008322108

Zayed H, Izsvák Z, Khare D, Heinemann U, Ivics Z (2003) The DNA-bending protein HMGB1 is a cellular cofactor of Sleeping Beauty transposition. Nucleic Acids Res 31:2313-2322. https://doi.org/10.1093/nar/gkg341

Publisher's Note Springer Nature remains neutral with regard to jurisdictional claims in published maps and institutional affiliations. 